\title{
Composition and distribution of the peracarid crustacean fauna along a latitudinal transect off Victoria Land (Ross Sea, Antarctica) with special emphasis on the Cumacea
}

\author{
Peter Rehm • Sven Thatje • Ute Mühlenhardt-Siegel • \\ Angelika Brandt
}

Received: 15 August 2006 / Revised: 6 December 2006 / Accepted: 10 December 2006 / Published online: 2 February 2007

(C) Springer-Verlag 2007

\begin{abstract}
The following study was the first to describe composition and structure of the peracarid fauna systematically along a latitudinal transect off Victoria Land (Ross Sea, Antarctica). During the 19th Antarctic expedition of the Italian research vessel "Italica" in February 2004, macrobenthic samples were collected by means of a Rauschert dredge with a mesh size of $500 \mu \mathrm{m}$ at depths between 85 and $515 \mathrm{~m}$. The composition of peracarid crustaceans, especially Cumacea was investigated. Peracarida contributed $63 \%$ to the total abundance of the fauna. The peracarid samples were dominated by amphipods (66\%), whereas cumaceans were represented with $7 \%$. Previously, only 13 cumacean species were known, now the number of species recorded from the Ross Sea increased to 34 . Thus, the cumacean fauna of the Ross Sea, which was regarded as the poorest in terms of species richness, has to be considered as equivalent to that of other high Antarctic areas. Most important cumacean families concerning abundance and species richness were Leuconidae, Nannastacidae, and Diastylidae. Cumacean diversity
\end{abstract}

\section{P. Rehm ( $\square)$}

Alfred Wegener Institute for Polar

and Marine Research (AWI), Marine Animal Ecology,

Am Alten Hafen 26, 27568 Bremerhaven, Germany

e-mail: peter.rehm@awi.de

\section{S. Thatje}

National Oceanography Centre, Southampton,

School of Ocean and Earth Science,

University of Southampton,

European Way, Southampton, SO14 3ZH, UK

U. Mühlenhardt-Siegel $\cdot$ A. Brandt

Zoologisches Institut und Museum, Universität Hamburg,

Martin-Luther-King Platz 3, 20146 Hamburg, Germany was lowest at the northernmost area (Cape Adare). At the area off Coulman Island, which is characterized by muddy sediment, diversity was highest. Diversity and species number were higher at the deeper stations and abundance increased with latitude. A review of the bathymetric distribution of the Cumacea from the Ross Sea reveals that most species distribute across the Antarctic continental shelf and slope. So far, only few deep-sea records justify the assumption of a shallowwater-deep-sea relationship in some species of Ross Sea Cumacea, which is discussed from an evolutionary point of view.

Keywords Diversity $\cdot$ Cumacea $\cdot$ Benthos .

Antarctica $\cdot$ Ross Sea

\section{Introduction}

Five of the seven peracarid orders are known to occur in Antarctic waters. Amphipoda are most diverse with 821 species in the Southern Ocean (De Broyer and Jazdzewski 1996), while 365 species of Isopoda are known for this area (Brandt 1999). Cumacea are represented with 66 species (87 including the Magellan area, Mühlenhardt-Siegel 1999), whereas Mysidacea and Tanaidacea are represented with 59 and 36 species, respectively (Brandt et al. 1998; Schmidt and Brandt 2001).

First research on Antarctic cumaceans started with the descriptions of Zimmer (1902, 1907a, b, 1908, 1909, 1913) and Calman (1907, 1917, 1918). Further work followed (e.g., Hale 1937; Gamô 1959, 1987; Lomakina 1968; Ledoyer 1973, 1977; Petrescu (1991); Petrescu and Wittman 2003), and a total of 58 species were mentioned by Ledoyer (1993). Mühlenhardt-Siegel 
(1999) summarized 66 cumacean species known from Antarctica. During the last years ten further species, such as Gynodiastylis jazdzewskii (Błażewicz and Heard 1999) from the Ross Sea, were described.

In "The fauna of the Ross Sea" (Jones 1971) merely ten cumacean species were mentioned; only two additional species were recorded during the last decades (Roccatagliata and Heard 1992; Błażewicz and Heard 1999). The species Makrokylindrus baceskei (Lomakina 1968) was reported from $2,937 \mathrm{~m}$ at the Balleny Islands only, but is counted as a Ross Sea species in this study. Thus prior to the present study, the number of cumacean species known from the Ross Sea was 13 . Approximately 30 cumacean species are known from other high Antarctic regions (Mühlenhardt-Siegel 1999; Corbera 2000). The great difference in species numbers known from different high Antarctic localities can be attributed to the little work, which has so far been accomplished on the deeper benthic environment of the northern Victoria-Land coast and the eastern Ross Sea (Waterhouse 2001) as well as the gear used for sampling. Conventional gear, such as dredges, trawls, and corers, most likely does not sample the cumacean fauna adequately (Jones and Sanders 1972). During previous expeditions to the Ross Sea, predominantly nets with wide mesh sizes were used for sampling. Cumaceans are small peracarids ranging between 0.1 and $3.5 \mathrm{~cm}$ in size (mostly less than $1 \mathrm{~cm}$ ). Therefore, most of the animals will be washed out of nets with mesh sizes of $1 \mathrm{~cm}$ and more.

The present study deals with the distribution of the peracarid orders along a latitudinal and depth transect and the faunistic composition of the cumaceans from the waters of the northern Victoria-Land coast. A Rauschert dredge with a mesh size of $500 \mu \mathrm{m}$ was used to gain data on abundance, diversity, and bathymetric distribution of the cumacean fauna.

\section{Materials and methods}

During the 19th Antarctic expedition with RV "Italica" in February 2004, 18 samples were taken along a latitudinal transect in the four areas of Victoria-Land coast Cape Adare, Cape Hallett, Coulman Island, and Cape Russell (Fig. 1; Table 1). Station Santa Maria Novella (Terra Nova Bay) and the stations off Cape Russell were pooled for further analysis since these stations were sampled in the same region. A depth gradient was sampled at each area: samples of area Cape Hallett were obtained from two depths transects inside and outside Cape Hallett Bay. Owing to severe ice conditions off Coulman Island, only two samples were taken in this area.

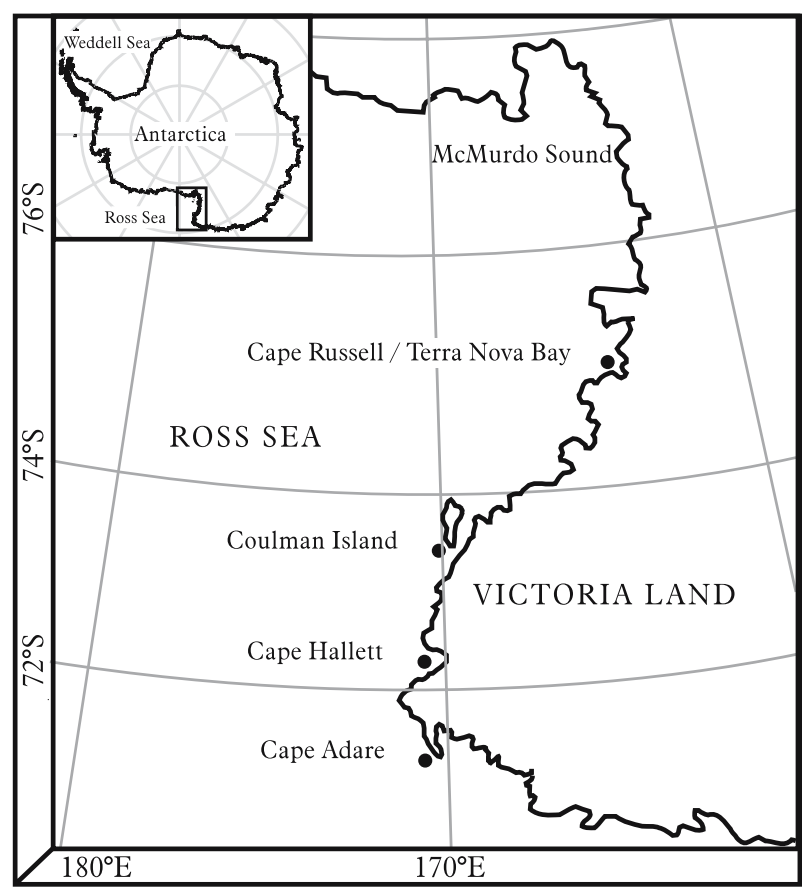

Fig. 1 Victoria-Land coast (Ross Sea, Antarctica); sample areas: Cape Adare, Cape Hallett, Coulman Island, and Cape Russell

A modified Rauschert dredge (Lörz et al. 1999) with a mesh size of $500 \mu \mathrm{m}$ and an opening of $0.5 \mathrm{~m}$ was used to take samples from water depth between 84 and $515 \mathrm{~m}$. A second inner net with a mesh size of $1 \mathrm{~cm}$ was used to keep larger objects out of the $500 \mu \mathrm{m}$ net. The dredge was hauled over the ground at a mean velocity of one knot. Haul lengths varied from 59 to $575 \mathrm{~m}$. For comparison between stations, samples were standardized for $1,000 \mathrm{~m}^{2}$ hauls. Before the material was preserved in $90 \%$ precooled ethanol and kept in $-25^{\circ} \mathrm{C}$ for later DNA extraction, it was sieved on a $500 \mu \mathrm{m}$ mesh. Afterwards in the laboratory a stereomicroscope was used to sort the samples into major taxonomic groups. Cumacea were identified to species level.

We applied univariate measures of diversity, the Shannon-Wiener index $\left(\mathrm{H}^{\prime}\right)$ (log base) (Shannon and Weaver 1949), and evenness ( $\mathrm{J}^{\prime}$ ) (Pielou 1966). A Multidimensional Scaling (MDS) analysis was carried out with the software package Primer (v. 5.1.2) of the Plymouth Marine Laboratory using Bray-Curtis Index to analyse the distribution of cumacean species assemblages in the study area. Because of the semi-quantitative nature of data derived from the dredge samples, arc-sin transformed relative abundances were used for analysis.

Due to technical problems during processing, a sample taken at station R4 was only analysed qualitatively. Additional material collected onboard of the New Zealand RV “Tangaroa” was analysed in order to 
Table 1 Rauschert dredge stations of the Victoria-Land transect cruise (Ross Sea, Antarctica) taken from onboard RV "Italica"

\begin{tabular}{|c|c|c|c|c|c|c|}
\hline \multirow[t]{2}{*}{ Station north to south } & \multirow[t]{2}{*}{ Date } & \multicolumn{2}{|l|}{ Position } & \multirow{2}{*}{$\begin{array}{l}\text { Depth } \\
(\mathrm{m})\end{array}$} & \multirow{2}{*}{$\begin{array}{l}\text { Haul length } \\
\text { (m) }\end{array}$} & \multirow[t]{2}{*}{ Sediment } \\
\hline & & latitude (S) & longitude $(\mathrm{E})$ & & & \\
\hline \multicolumn{7}{|l|}{ Cape Adare } \\
\hline A1 & $15 / 02 / 2004$ & $71^{\circ} 15.5^{\prime}$ & $170^{\circ} 41.9^{\prime}$ & 515 & 358 & Sand with few pebbles and stones \\
\hline A2 & $14 / 02 / 2004$ & $71^{\circ} 17.3^{\prime}$ & $170^{\circ} 39.2^{\prime}$ & 421 & 298 & Sand and gravel \\
\hline A3 & $14 / 02 / 2004$ & $71^{\circ} 18.7^{\prime}$ & $170^{\circ} 29.2^{\prime}$ & 305 & 257 & Sand \\
\hline A4 & $14 / 02 / 2004$ & $71^{\circ} 18.4^{\prime}$ & $170^{\circ} 28.9^{\prime}$ & 230 & 376 & Sand and pebbles \\
\hline A5 & $15 / 02 / 2004$ & $71^{\circ} 18.7^{\prime}$ & $170^{\circ} 25.5^{\prime}$ & 119 & 59 & Sand with pebbles and stones \\
\hline \multicolumn{7}{|l|}{ Cape Hallett } \\
\hline H out 1 & $09 / 02 / 2004$ & $72^{\circ} 15.7^{\prime}$ & $170^{\circ} 24.8^{\prime}$ & 458 & 375 & Mud and pebbles \\
\hline $\mathrm{H}$ out 2 & $11 / 02 / 2004$ & $72^{\circ} 17.5^{\prime}$ & $170^{\circ} 29.4^{\prime}$ & 353 & 375 & Sandy mud and stones \\
\hline H out 4 & $12 / 02 / 2004$ & $72^{\circ} 18.5^{\prime}$ & $170^{\circ} 26.8^{\prime}$ & 235 & 194 & Sand \\
\hline $\mathrm{H}$ in 2 & $10 / 02 / 2004$ & $72^{\circ} 16.9^{\prime}$ & $170^{\circ} 12.2^{\prime}$ & 391 & 186 & Coarse sand and small gravel \\
\hline $\mathrm{H}$ in 3 & $16 / 02 / 2004$ & $72^{\circ} 17.0^{\prime}$ & $170^{\circ} 13.1^{\prime}$ & 316 & 194 & Muddy sand with stones \\
\hline $\mathrm{H}$ in 4 & $16 / 02 / 2004$ & $72^{\circ} 17.1^{\prime}$ & $170^{\circ} 14.0^{\prime}$ & 196 & 169 & Mud and sand \\
\hline $\mathrm{H}$ in 5 & $16 / 02 / 2004$ & $72^{\circ} 17.2^{\prime}$ & $170^{\circ} 17.9^{\prime}$ & 84 & 113 & Small gravel \\
\hline \multicolumn{7}{|l|}{ Coulman Island } \\
\hline $\mathrm{C} 1$ & $18 / 02 / 2004$ & $73^{\circ} 24.5^{\prime}$ & $170^{\circ} 23.2^{\prime}$ & 474 & 375 & Mud and small gravel \\
\hline $\mathrm{C} 2$ & $18 / 02 / 2004$ & $73^{\circ} 22.7^{\prime}$ & $170^{\circ} 06.9^{\prime}$ & 410 & 153 & Mud and pebbles \\
\hline \multicolumn{7}{|l|}{ Cape Russell } \\
\hline SMN & $20 / 02 / 2004$ & $74^{\circ} 43.2^{\prime}$ & $164^{\circ} 13.1^{\prime}$ & 366 & 192 & Sand with gravel and stones \\
\hline $\mathrm{R} 2$ & $21 / 02 / 2004$ & $74^{\circ} 49.0^{\prime}$ & $164^{\circ} 18.1^{\prime}$ & 364 & 575 & Fine sand \\
\hline R3 & $20 / 02 / 2004$ & $74^{\circ} 49.3^{\prime}$ & $164^{\circ} 11.5^{\prime}$ & 330 & 565 & Rock, sand, mud and pebbles \\
\hline $\mathrm{R} 4$ & $20 / 02 / 2004$ & $74^{\circ} 49.3^{\prime}$ & $164^{\circ} 11.5^{\prime}$ & 208 & 97 & Rock, mud and large stones \\
\hline $\mathrm{R} 4$ & $22 / 02 / 2004$ & $74^{\circ} 50.2^{\prime}$ & $164^{\circ} 05.5^{\prime}$ & 216 & - & Rock, mud \\
\hline
\end{tabular}

enhance the species inventory list of the Ross Sea cumacean fauna.

\section{Results}

Distribution of the peracarid fauna off Victoria Land

During the Victoria-Land cruise $63 \%$ of the collected macrobenthic fauna were peracarid crustaceans. In total 45,087 specimens of Peracarida were collected, 5,286 of which belonged to the order of Cumacea.

Amphipoda were the dominant peracarid taxon $(66 \%)$ followed by Isopoda (18\%), Tanaidacea $(8 \%)$, Cumacea $(7 \%)$, and Mysidacea $(<1 \%)$. Abundance values varied remarkably among stations and peracarid groups (Table 2). The highest total abundance of peracarids was found at the shallowest station $(\mathrm{H}$ in 5 ; $84 \mathrm{~m}$ ) off Cape Adare.

The Cumacea showed a tendency of increasing relative abundance from north to south (Fig. 2): it ranged from $0.5 \%$ in the north at Cape Adare to $36 \%$ in the south at Cape Russell. In contrast the proportion of Amphipoda was higher in the northern (Cape Adare $63 \%$, Cape Hallett $69 \%$ ) than in the southern areas (Coulman Island 27\%, Cape Russell 36\%). The relative abundance of Tanaidacea was three times higher at Coulman Island (31\%) than in the other areas $(6-10 \%)$. Isopod abundance was highest at Cape Russell, but varied less than in the other peracarid groups (14-26\%). Mean abundance of Amphipoda, Isopoda, and Tanaidacea was highest at the shallowest stations, whereas Cumacea and Mysidacea showed maximum abundances at stations from 300 to $400 \mathrm{~m}$ (Table 3).

Composition, distribution and diversity of Cumacea off Victoria Land

All five cumacean families known from the Antarctic and 12 genera were represented in the samples. 19 of the 28 cumacean species found in the samples are new records for the Ross Sea. In addition two new records of cumacean species were collected with RV "Tangaroa" (Table 4), thus the number of recorded species totals 34 . Leuconidae containing nine species from two genera were the most dominant cumacean family (69\%). The genus Leucon (6 species) was most abundant $(57 \%)$. Nannastacidae, comprising nine species of three genera, occurred with $21 \%$. The family Diastylidae ( 7 species, 4 genera) made up $6 \%$ of total cumacean abundance. Only two species of two genera of Bodotriidea and Lampropidae were collected which represented $3 \%$ and less than $1 \%$, respectively, of cumacean specimens. 
Table 2 Abundance of Peracarida along the Victoria-Land coast

\begin{tabular}{|c|c|c|c|c|c|c|c|c|c|c|}
\hline \multirow[t]{2}{*}{ Station north to south } & \multicolumn{2}{|c|}{ Amphipoda } & \multicolumn{2}{|c|}{ Cumacea } & \multicolumn{2}{|c|}{ Isopoda } & \multicolumn{2}{|c|}{ Mysidacea } & \multicolumn{2}{|c|}{ Tanaidacea } \\
\hline & $\mathrm{N}$ & $\mathrm{N} 10^{3} \mathrm{~m}^{-2}$ & $\mathrm{~N}$ & $\mathrm{~N} 10^{3} \mathrm{~m}^{-2}$ & $\mathrm{~N}$ & $\mathrm{~N} 10^{3} \mathrm{~m}^{-2}$ & $\overline{\mathrm{N}}$ & $\mathrm{N} 10^{3} \mathrm{~m}^{-2}$ & $\mathrm{~N}$ & $\mathrm{~N} 10^{3} \mathrm{~m}^{-2}$ \\
\hline \multicolumn{11}{|l|}{ Cape Adare } \\
\hline A1 & 244 & 1,363 & 2 & 11 & 23 & 128 & 17 & 95 & 40 & 223 \\
\hline A2 & 1,567 & 10,517 & 0 & 0 & 173 & 1,161 & 14 & 94 & 285 & 1,913 \\
\hline A3 & 682 & 5,307 & 2 & 16 & 605 & 4,708 & 4 & 31 & 57 & 444 \\
\hline A4 & 1,209 & 6,431 & 37 & 197 & 1,034 & 5,500 & 3 & 16 & 271 & 1,441 \\
\hline A5 & 505 & 17,119 & 3 & 101 & 68 & 2,305 & 1 & 34 & 75 & 2,542 \\
\hline \multicolumn{11}{|l|}{ Cape Hallett } \\
\hline H out 1 & 636 & 3,392 & 114 & 608 & 301 & 1,605 & 0 & 0 & 88 & 469 \\
\hline H out 2 & 846 & 4,512 & 66 & 352 & 277 & 1,477 & 0 & 0 & 45 & 240 \\
\hline H out 4 & 2,357 & 24,299 & 65 & 670 & 1,050 & 10,825 & 6 & 62 & 154 & 1,588 \\
\hline $\mathrm{H}$ in 2 & 159 & 1,710 & 107 & 1,151 & 78 & 839 & 4 & 43 & 22 & 237 \\
\hline $\mathrm{H}$ in 3 & 991 & 10,216 & 297 & 3,062 & 450 & 4,639 & 0 & 0 & 181 & 1,866 \\
\hline $\mathrm{H}$ in 4 & 3,185 & 37,692 & 219 & 2,586 & 1,449 & 17,148 & 0 & 0 & 486 & 5,751 \\
\hline $\mathrm{H}$ in 5 & 10,170 & 180,000 & 56 & 991 & 882 & 15,611 & 0 & 0 & 490 & 8,673 \\
\hline \multicolumn{11}{|l|}{ Coulman Island } \\
\hline $\mathrm{C} 1$ & 57 & 304 & 10 & 53 & 36 & 192 & 3 & 16 & 27 & 144 \\
\hline $\mathrm{C} 2$ & 711 & 9,294 & 315 & 4,116 & 676 & 8,837 & 2 & 26 & 838 & 10,954 \\
\hline \multicolumn{11}{|l|}{ Cape Russell } \\
\hline SMN & 1,413 & 14,719 & 1,252 & 13,050 & 1,080 & 11,250 & 42 & 438 & 448 & 4,667 \\
\hline $\mathrm{R} 2$ & 1,016 & 3,534 & 1,354 & 4,706 & 729 & 2,536 & 0 & 0 & 75 & 261 \\
\hline R3 & 694 & 2,457 & 1,374 & 4,864 & 516 & 1,827 & 26 & 92 & 78 & 276 \\
\hline $\mathrm{R} 4$ & 97 & 2,000 & 14 & 288 & 41 & 845 & 1 & 21 & 11 & 227 \\
\hline
\end{tabular}

$N=$ number of specimens collected per station, $N 10^{3} \mathrm{~m}^{-2}=$ number of specimens per station standardized to $1,000 \mathrm{~m}^{2}$

Fig. 2 Relative numbers of peracarid taxa in the sample areas on the Ross Sea shelf, Antarctica

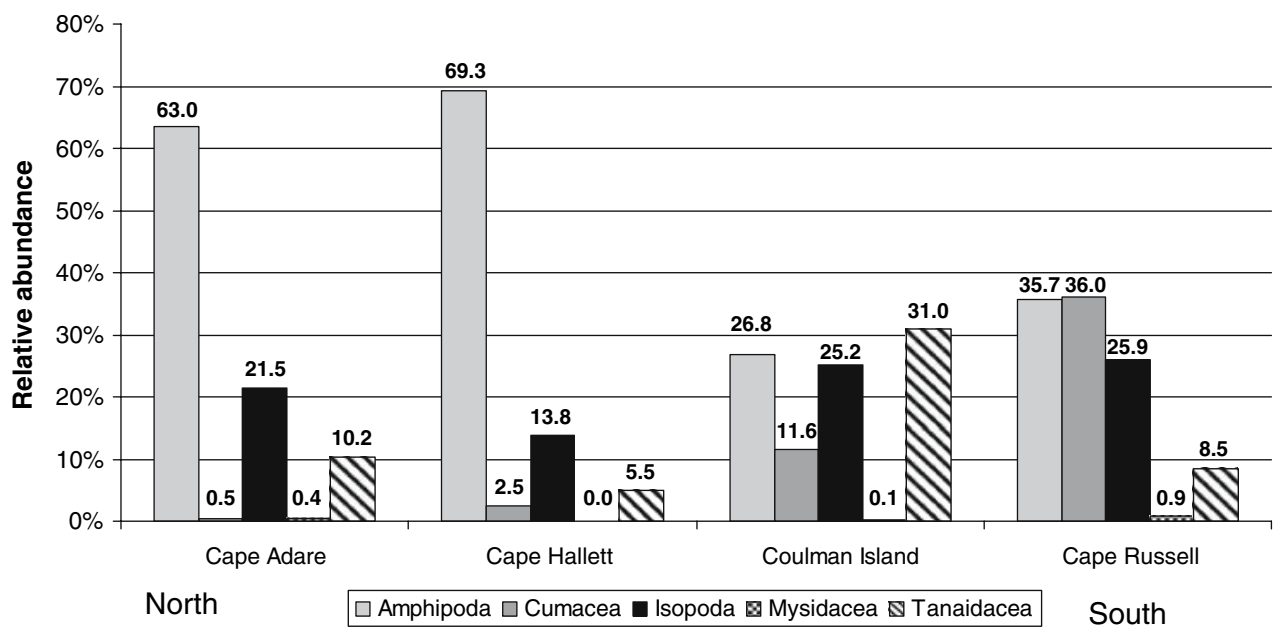

Table 3 Peracarid abundance per $1,000 \mathrm{~m}^{-2}$, averaged across four depth zones off Victoria Land, Ross Sea

\begin{tabular}{lrrrlr}
\hline Depth range $(\mathrm{m})$ & Amphi & Cuma & Isop & Mysid & Tana \\
\hline $84-200$ & 78,270 & 1,226 & 11,688 & 11 & 5,655 \\
$201-300$ & 4,216 & 243 & 3,173 & 19 & 834 \\
$301-400$ & 6,565 & 3,886 & 3,897 & 86 & 1,142 \\
$401-515$ & 8,195 & 910 & 3,791 & 49 & 2,549 \\
\hline
\end{tabular}

Amphi Amphipoda, Cuma Cumacea, Isop Isopoda, Mysid Mysidacea, Tana Tanaidacea

Most species were found between 200 and $450 \mathrm{~m}$ depth. From 100 to about $200 \mathrm{~m}$ only six species were found, whereas nine species were confined to depths below $300 \mathrm{~m}$ (Fig. 3). Diversity varied considerably $\left(\mathrm{H}^{\prime}: 0-2.5 ; \mathrm{J}^{\prime}: 0.45-0.83\right)$ and was highest at station $\mathrm{C} 2$ off Coulman Island, which also was the station with the highest number of species (20). Diversity was lowest at stations A1, A3, and A5 off Cape Adare, for only one species was represented at these stations (Table 5). Accordingly, Cape Adare was the area with the lowest mean values of diversity, number of species, and abundance, whereas off Coleman Island mean diversity and mean species number were highest. Cumacean mean abundance increased with latitude (Table 6). Mean diversity and evenness showed a tendency to higher values at deeper stations; mean species number, 
Table 4 Cumacean species of the Ross Sea; species collected during the expeditions of RV "Italica" (Ita) and "Tangaroa" (Tan) in 2004, $n=$ new record from the Ross Sea

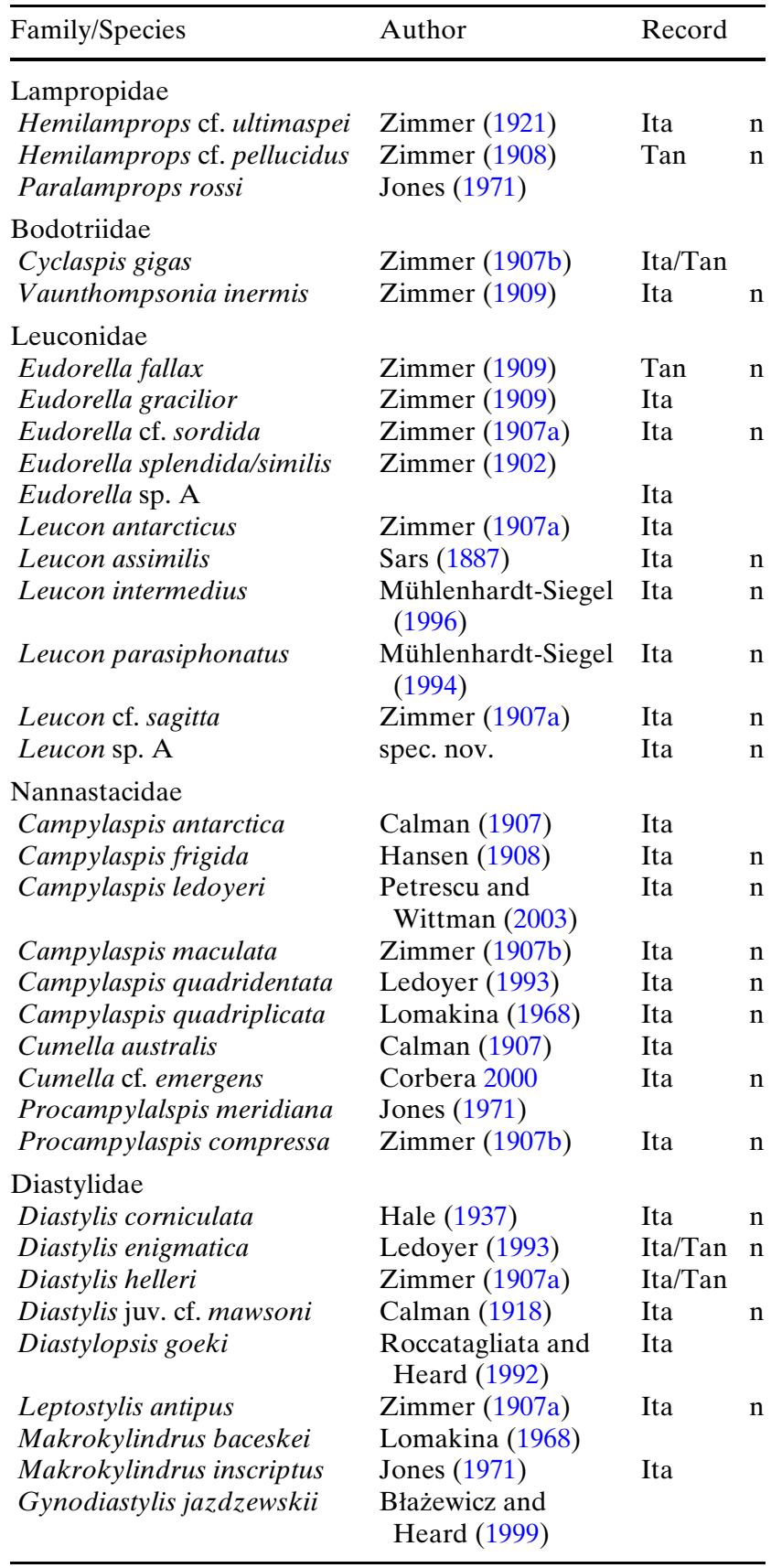

abundance, and diversity were highest at stations between 301 and $400 \mathrm{~m}$ (Table 7).

After the MDS analysis stations were roughly arranged corresponding to their geographical order (Fig. 4). The only exception was station A1 (Cape Adare), which was clearly different to the remaining stations. Species, which only occurred in one area, were found. Thus the species Eudorella sp. A and Makrokylindrus inscriptus were only recorded from Cape Hallett. Leucon parasiphonatus and Diastylopsis goeki solely occurred off Coulman Island. Species confined to Cape Russell were Campylaspis frigida and Diastylis enigmatica. No species occurred exclusively at Cape Adare.

\section{Discussion}

Almost nothing has been known about sub-tidal ecosystems off the northern Victoria-Land coast, and most recent studies of shallow benthic communities in the Ross Sea focused rather on ecological interactions than on classifications (Waterhouse 2001). A first attempt to describe the community structure of smaller macrozoobenthic species along the northern Victoria-Land coast was made onboard of the 19th expedition of RV "Italica" (Rehm et al. 2006).

Gears with small mesh sizes, such as the Rauschert dredge or epibenthic sledges, are very effective for sampling smaller peracarid crustaceans. As the Rauschert dredge (see Rehm et al. 2006) was used for the first time in the Ross Sea, it gave us a first insight into the peracarid community of the northern VictoriaLand coast and helped to considerably improve our knowledge of cumaceans from the Ross Sea.

\section{Comparison of the peracarid fauna}

The peracarid community sampled during the 19th Italian expedition with research vessel "Italica" was dominated by amphipods. Isopods represented the second dominant group, followed by Tanaidacea, Cumacea, and Mysidacea. Only few quantitative studies of peracarids sampled with gears with small mesh size were so far carried out in Antarctic waters. Samples taken off the South Shetland Islands at depth between 200 and $400 \mathrm{~m}$ and taken with an epibenthic sledge in autumn 2000 showed comparable results in the mean proportions of peracarid orders: $62 \%$ Amphipoda, 16\% Isopoda, 13\% Tanaidacea, $11 \%$ Cumacea, and less than 1\% Mysidacea (Lörz and Brandt 2003). Nevertheless, samples taken during summer in the southern Weddell Sea and off King George Island in depths ranging from 200 to $400 \mathrm{~m}$ showed different values (Linse et al. 2002); Isopoda $60 \%$, Amphipoda $26 \%$, Mysidacea $10 \%$, Cumacea $4 \%$, and Tanaidacea $1 \%$ in the Weddell Sea; Cumacea $39 \%$, Amphipoda $31 \%$, Mysidacea $17 \%$, Isopoda $13 \%$, and Tanaidacea $1 \%$ off King George Island. Differences in the gear are one explanation for the variations in the results of the different studies. The epibenthos sledge samples from over $20 \mathrm{~cm}$ to more than $120 \mathrm{~cm}$ above the seafloor (Brandt and Barthel 1995; Brenke 2005), but the Rauschert dredge is bound to the first about $18 \mathrm{~cm}$ above the ground. Thus, the increased number of 


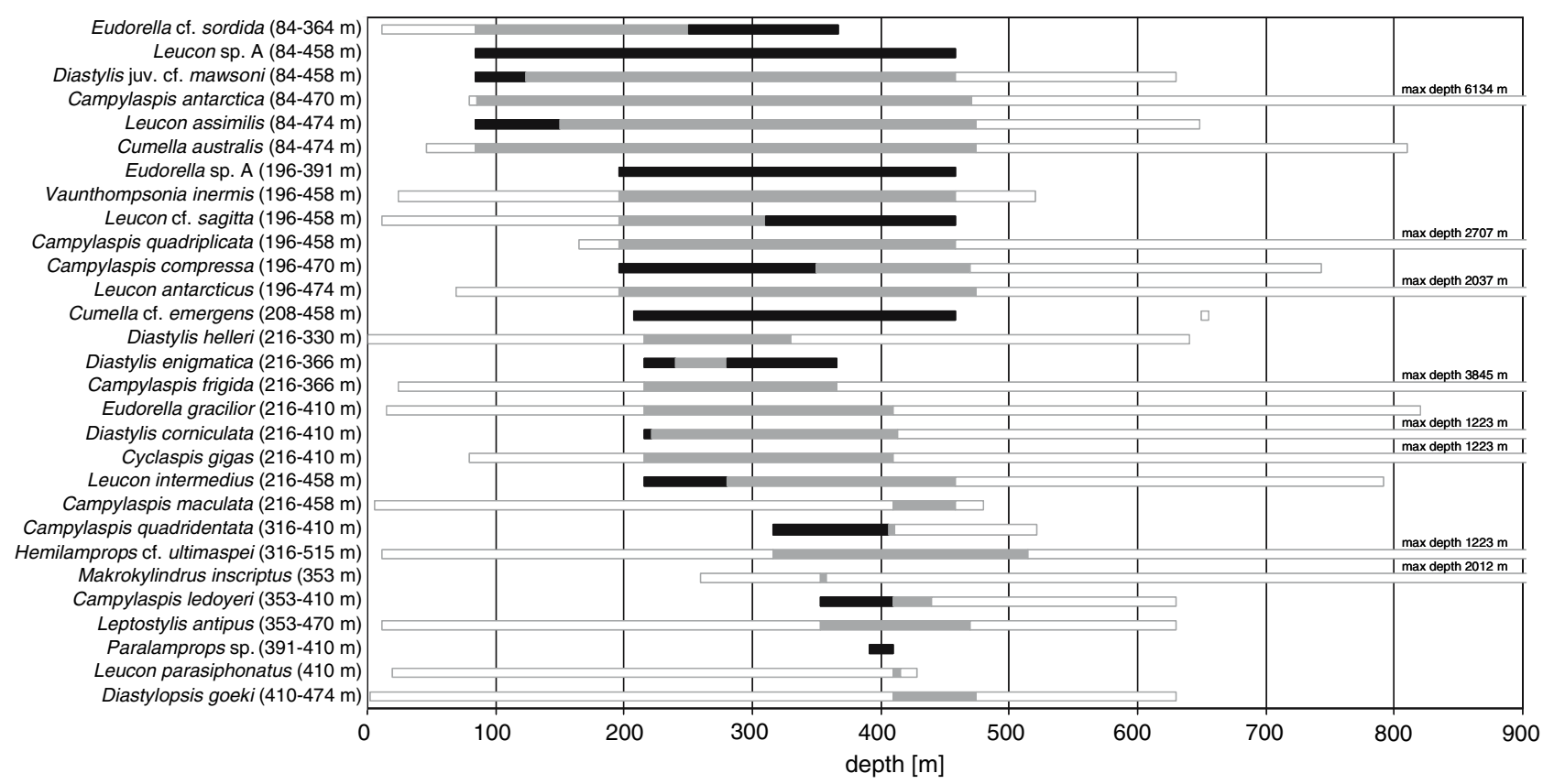

Fig. 3 Bathymetric distribution of the Cumacea collected during the Victoria-Land transect cruise to the Ross Sea, Antarctica (black shade); general depth range (white shade), data based on
Jones (1971, 1984) Ledoyer (1993), Mühlenhardt-Siegel (1999), Corbera (2000), Petrescu and Wittman (2003), Corbera and Ramos (2005); overlapping depth range (grey shade)
Mysidacea in the epibenthic sledge samples might be attributed to their suprabenthic life style. However, only few mysids were sampled with the epibenthic sledge in autumn 2000. Variations of the contribution of peracarid orders to the peracarid fauna were high during all studies and the number of samples from shallower water than $500 \mathrm{~m}$ depth taken in the Weddell Sea and the South Shetland Islands was limited. Therefore, it is difficult to judge whether differences might result from the patchiness of the fauna obtained, a different compositions of the fauna, or seasonal effects. Further sampling with and comparison of multiple gears will provide more reliable information about seasonal differences and similarities between the different Antarctic areas.

\section{Composition and distribution of the cumacean fauna}

In the Weddell Sea as around the South Shetland Islands (Corbera 2000; Lörz and Brandt 2003) most speciose family was the Nannastacidae. In the Ross Sea, the most abundant family was the Leuconidae, whereas the Diastylidae (Lörz and Brandt 2003) or Bodotriidae (Corbera 2000) dominated the cumaceans off the South Shetland Islands. Mean species number off the South Shetland Islands was half of the Ross Sea, whereas total species number varied between 50 (Lörz and Brandt 2003) and 100\% (Corbera 2000).

Cumacean diversity index was higher at deeper stations and maximal in a depth of $410 \mathrm{~m}$ at station $\mathrm{C} 2$, which was one of the stations with muddy sediment. At the South Shetland Islands, cumacean diversity was extremely variable. Nevertheless, a tendency towards higher values at deeper stations was recorded as well; this trend extended to depths below $500 \mathrm{~m}$ on the continental slope (Corbera 2000). Density and species number of the Cumaceans of the Beagle Channel was found to increase with depth and reduced grain size of the sediment (Brandt et al. 1999).

During this study one group of species was found ranging from 100 to $500 \mathrm{~m}$, a second group of species was found in between 200 and $500 \mathrm{~m}$, and a third group ranges from 300 to $500 \mathrm{~m}$. From the Weddell Sea, three bathymetric groups of cumaceans were reported between 200 and $500-600 \mathrm{~m}$, below $500 \mathrm{~m}$, and finally between 200 and 2,000 $\mathrm{m}$ (Ledoyer 1993). Corbera (2000) described a situation with three groups between 45 and $300 \mathrm{~m}, 300$ and $650 \mathrm{~m}, 45$ and $650 \mathrm{~m}$. Concluding from the three stydies, there appear to be two important changes in cumacean depth distribution around 300 and 500-600 $\mathrm{m}$ depth.

The most striking result of this work is the large number of newly recorded cumacean species from the Ross Sea. One reason to explain this remarkable increase in known species can be ascribed to the little previous work from the area under investigation, which has now been accomplished on the deeper benthic environment, between $50 \mathrm{~m}$ and the shelf break at $800 \mathrm{~m}$ (Clark and Rowden 2004; Waterhouse 2001). The new species 


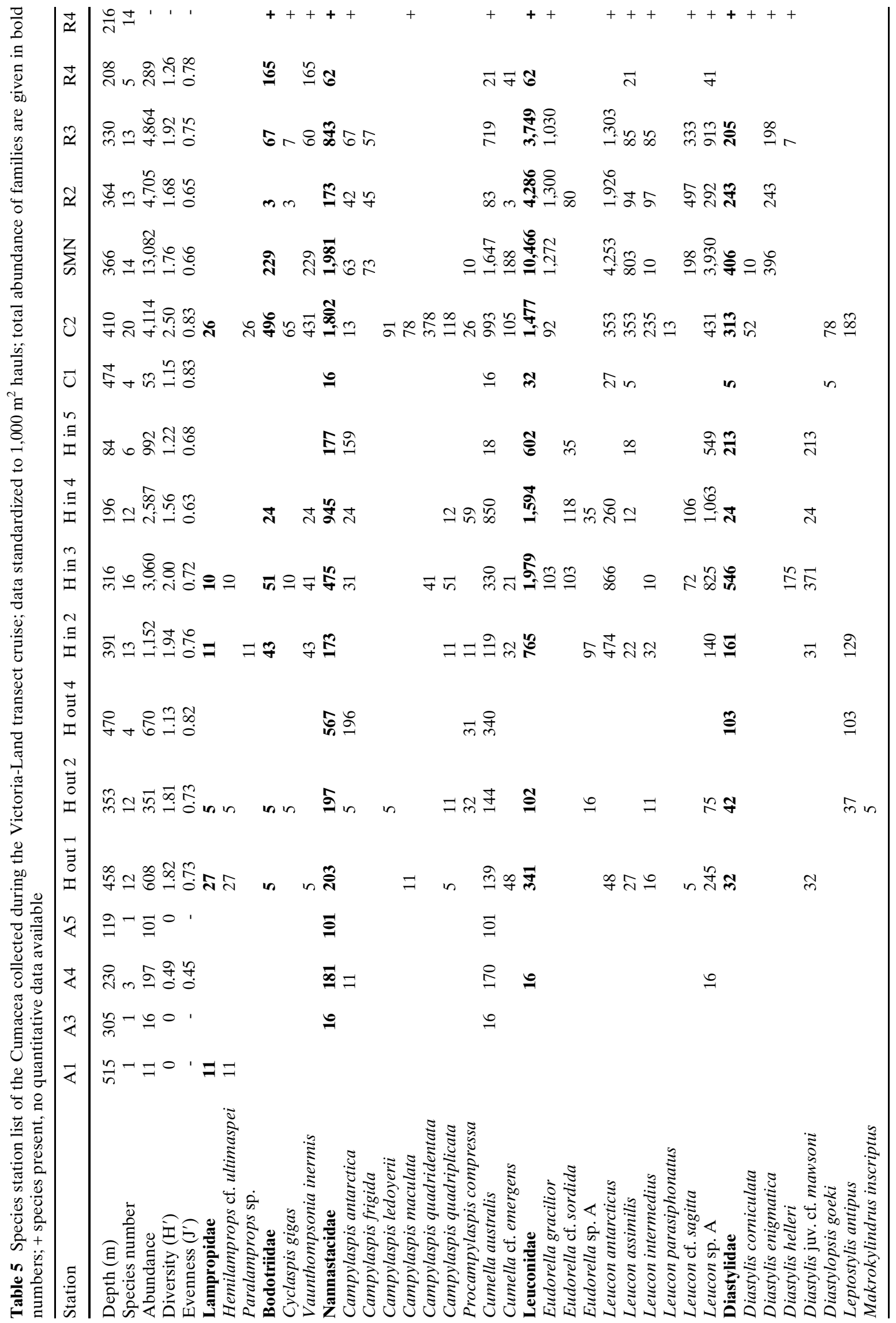


Table 6 Average measurements of cumacean diversity by latitude (Victoria-Land transect, Ross Sea)

\begin{tabular}{llrrr}
\hline $\begin{array}{l}\text { Sample area } \\
\text { north to south }\end{array}$ & S mean/total & $\mathrm{N}$ & $\mathrm{H}^{\prime}$ & $\mathrm{J}^{\prime}$ \\
\hline Cape Adare & $2 / 4$ & 81 & 0.45 & 0.12 \\
Cape Hallett & $11 / 24$ & 1,346 & 0.72 & 1.64 \\
Coulman Island & $12 / 20$ & 2,084 & 0.83 & 1.82 \\
Cape Russell & $11 / 17$ & 5,727 & 0.71 & 1.65 \\
\hline
\end{tabular}

$S$ species number, $N$ abundance per $1,000 \mathrm{~m}^{2}, H^{\prime}$ diversity, $J^{\prime}$ evenness

Table 7 Average measurements of cumacean diversity by depth (Victoria-Land transect, Ross Sea)

\begin{tabular}{llrll}
\hline Depth range $(\mathrm{m})$ & $\mathrm{S}$ mean/total & $\mathrm{N}$ & $\mathrm{H}^{\prime}$ & $\mathrm{J}^{\prime}$ \\
\hline $84-200$ & $6 / 12$ & 1,227 & 0.92 & 0.65 \\
$201-300$ & $4 / 15$ & 243 & 0.87 & 0.61 \\
$301-400$ & $12 / 26$ & 3,885 & 1.59 & 0.71 \\
$401-515$ & $8 / 23$ & 1,091 & 1.32 & 0.80 \\
\hline
\end{tabular}

$\overline{S \text { species number, } N \text { abundance per } 1,000 \mathrm{~m}^{2}, H^{\prime} \text { diversity, } J^{\prime}}$ evenness

Leucon sp. A shows that the area is truly undersampled, as the species was one of the most common species with up to 2,000 specimen per square meter in the present study. Only Leucon antarcticus occurred more frequently. Leucon sp. A was found along the whole Victoria-Land coast and it was missing only at the deepest samples below $460 \mathrm{~m}$. In addition, this species is very easy to distinguish from other species of the genus $\mathrm{Leu}$ con. Nevertheless, there has been no data published about this species before. What might be even more important for the many species newly recorded from the Ross Sea was the use of a Rauschert dredge, as this gear is specially designed to catch animals of small size. In the case of the Cumacea, the number of species, which were reported for the Ross Sea before, increased from 13 to 32 species. Moreover, two further species, Hemilamprops cf. pellucidus and Eudorella fallax were found on the parallel cruise with RV "Tangaroa". Thus, 34 species are recorded in total for the Ross Sea. We expect that investigations of the other peracarid orders will lead to similar results.

A summary of the Antarctic cumacean species and their distribution in the Antarctic and Subantarctic regions was given by Mühlenhardt-Siegel (1999). The highest numbers of cumacean species were recorded from the East Antarctic (32), the Magellan region (31), and the Weddell Sea (29). In the Scotia region numbers varied between 15 and 20 species, whereas, in the Ross Sea only 11 species were recorded. Here we documented that the Ross Sea harbours more cumacean species than the other high Antarctic regions, although it was formerly regarded as the poorest Antarctic area concerning cumacean species richness. This finding highlights the need for more explorative sampling in the Ross Sea area and in deeper waters off the continental slope off Antarctica.

Most species from the Ross Sea show a wide range of geographic distribution (Table 8). Fifteen species occur in Antarctic regions, seven species are restricted to high Antarctic regions. Antarcto-Magellan species divide into a Subantarctic/Antarctic (6) and a Subantarctic/high Antarctic (2) group. The species of the latter group are probably also Subantarctic/Antarctic. After all, seven species making up $21 \%$ of the species from the Ross Sea occur in the Magellan area as well as in the Ross Sea. The species
Fig. 4 MDS-plot of Ross Sea Cumacea; $A$ Cape Adare, $H$ Cape Hallett, $C$ Coulman Island, $R$ Cape Russell, $S M N$ Santa Maria Novella

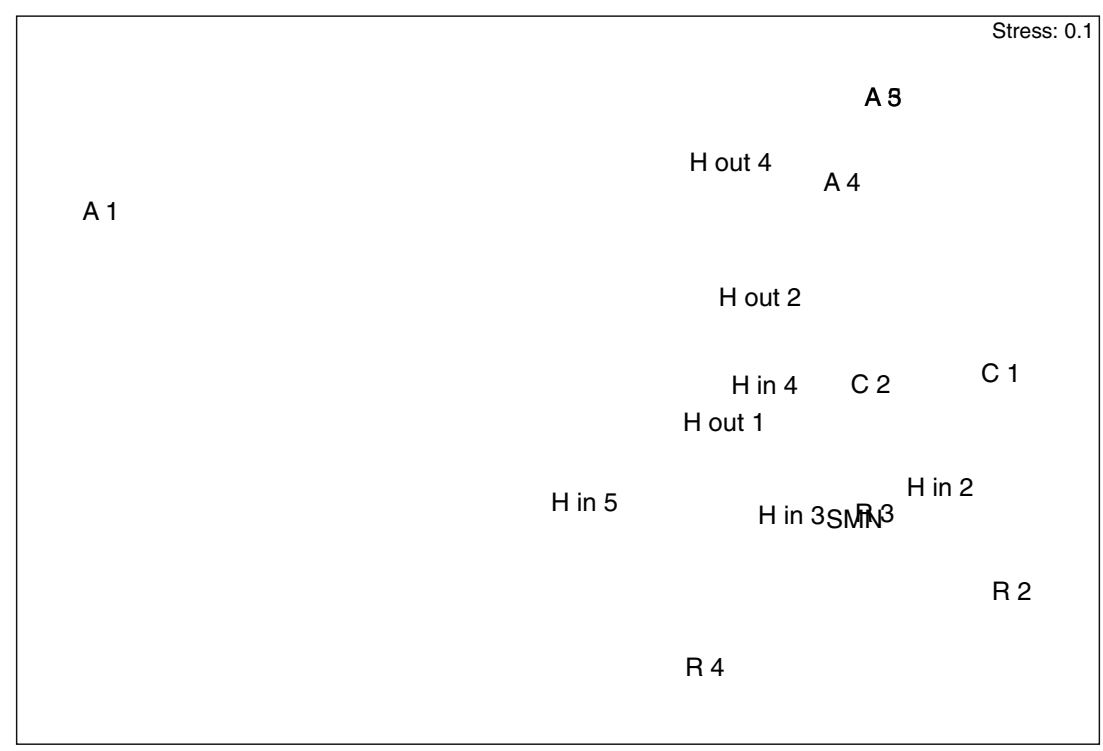


Table 8 Biogeography of cumacean species from the Ross Sea; data based on Hansen (1908), Mühlenhardt-Siegel (1999), Petrescu and Wittman (2003), Corbera and Ramos (2005), the present study and unpublished data from the BENTART-06 ${ }^{1}$ cruise (J. Corbera, pers. comm.) and the ANT XXI-2 $2^{2}$ cruise with RV "Polarstern"

\begin{tabular}{|c|c|c|c|c|c|c|c|c|c|}
\hline \multirow[t]{2}{*}{ Species } & \multicolumn{2}{|c|}{ Subantarctic } & \multicolumn{7}{|c|}{ Antarctic } \\
\hline & Magel & Kerg & S Geo & S Ork & S Shetl & Ant $\mathrm{P}$ & Wedd & BS & E Ant \\
\hline \multicolumn{10}{|l|}{ Subantarctic and Antarctic } \\
\hline Campylaspis maculata & + & & + & + & + & + & + & & + \\
\hline Campylaspis antarctica & + & & & & + & & + & $+{ }^{1}$ & + \\
\hline Eudorella splendida/similis & & + & + & & + & & & & \\
\hline Hemilamprops ultimaspei & + & & & & + & & + & & \\
\hline Leucon assimilis & + & + & & & + & + & + & & + \\
\hline Leucon sagitta & + & + & + & + & + & + & & & + \\
\hline \multicolumn{10}{|l|}{ Antarctic } \\
\hline Cumella australis & & & + & + & + & + & + & + & + \\
\hline Cumella cf. emergens & & & & & + & & $+^{2}$ & $+{ }^{1}$ & \\
\hline Cyclaspis gigas & & & + & & + & + & + & + & + \\
\hline Diastylis corniculata & & & & + & + & & + & & + \\
\hline Diastylopsis goeki & & & & + & + & + & + & & + \\
\hline Diastylis helleri & & & + & + & + & + & + & & + \\
\hline Eudorella fallax & & & + & + & + & + & & & + \\
\hline Eudorella gracilior & & & + & + & + & + & + & & + \\
\hline Eudorella cf. sordida & & & + & & & & & & \\
\hline Hemilamprops cf. pellucidus & & & & & + & + & + & & + \\
\hline Leptostylis antipus & & & + & + & + & + & + & & \\
\hline Leucon antarcticus & & & & + & & + & + & & + \\
\hline Leucon intermedius & & & & & + & + & $t^{2}$ & & + \\
\hline Leucon parasiphonatus & & & & & + & & + & & \\
\hline Vaunthompsonia inermis & & & + & + & + & + & + & + & + \\
\hline \multicolumn{10}{|l|}{ high Antarctic } \\
\hline Campylaspis quadridentata & & & & & & & + & & + \\
\hline Diastylis enigmatica & & & & & & & + & & \\
\hline Diastylis juv. cf. mawsoni & & & & & & & + & + & + \\
\hline Makrokylindrus inscriptus & & & & & & & + & & \\
\hline Paralamprops rossi & & & & & & & + & & + \\
\hline Procampylaspis compressa & & & & & & & + & + & \\
\hline \multicolumn{10}{|l|}{ Subantarctic and high Antarctic } \\
\hline Campylaspis frigida & + & + & & & & & & + & \\
\hline Campylaspis quadriplicata & + & & & & & & + & + & \\
\hline Ross Sea & & & & & & & & & \\
\hline Leucon sp. A & & & & & & & & & \\
\hline Procampylalspis meridiana & & & & & & & & & \\
\hline Makrokylindrus baceskei & & & & & & & & & \\
\hline Gynodiastylis jazdzewskii & & & & & & & & & \\
\hline
\end{tabular}

Ant P Antarctic Peninsula, BS Bellingshausen Sea E Ant East Antarctic, Kerg Kerguelen, Magel Magellan Area, $S$ Geo South Georgia, $S$ Ork South Orkneys, $S$ Shetl South Shetlands, Wedd Weddel Sea

of both areas total to 66 . An overlap of $11 \%$ is the same rate as reported for the Magellan area and Antarctica (Mühlenhardt-Siegel 1999). Four species $(11 \%)$ are endemic to the Ross Sea, the rate of endemism is less than in the Weddell Sea $(28 \%)$ and in the East Antarctic (13\%) (Corbera 2000). In conclusion, not only species number but also biogeographical connection to the Magellan area of the cumaceans of the Ross Sea resembles that of other high Antarctic regions. Still, the rate of endemism is the lowest of high Antarctic areas and similar to the East Antarctic only.
In several cases the determination of the species was difficult, as some of the original descriptions show only parts of the animal or the drawings are vague. We believe that good re-descriptions are necessary to simplify future work on Antarctic cumaceans. Another problem was that some of the species showed slight but consistent differences to specimens from original descriptions. It is rather likely these species show geographic variations, but there is also a chance that we found sibling species. Genetic analysis of the Antarctic isopod species Ceratoserolis trilobitoides demonstrated that sibling species, which were described as variations 
before (Wägele 1986), were even found in the same location (Held 2003). Possibly this is true for other Antarctic peracarid crustaceans as well. The Ross Sea is the southernmost ocean on earth and in contrast to most other Antarctic regions it is characterized by a very wide continental shelf. Furthermore, the Ross Sea polynya encloses the most productive phytoplankton primary production found in Antarctica (Smith et al. 1996), which might particularly foster benthic diversity.

Morphological variability in the Antarctic Cumacea and cryptic speciation, as already proven in Antarctic peracarid isopods (Held 2003; Held and Wägele 2005), are an indication of recurrent isolation processes of populations on an evolutionary timescale. Considering that most species of the Ross Sea Cumacea have a limited depth distribution that only covers the Antarctic continental shelf and slope, the deep-sea might not have served as refuge for many species during glacial ice advance in Antarctica (Thatje et al. 2005). This again poses the question of isolated shallow water refuges for benthic fauna in glacial periods and under severest environmental conditions (for discussion see Thatje et al. 2005). Such geographically isolated shelters, in addition, might have driven speciation process in the Peracarida, which have flourished in Antarctica. Molecular studies are needed to unravel this important and controversial question in the evolution of the Antarctic fauna.

Acknowledgments The authors are grateful to Prof. R. Cattaneo Vietti for the invitation to participate at the 19th expedition of the Programma Nazionale di Ricerche in Antartide (S.C.r.l.). We are also very grateful to Dr. M. Chiantore, Dr. S. Gatti, and Dr. O. Heilmayer for planning and their help during the cruise, to Dr. A. N. Lörz for providing the material collected on board of RV "Tangaroa", and to the crew of RV "Italica" for help and assistance at sea. Special thanks go to Dr. D. Roccatagliata for his support in determining the cumaceans collected. Thanks are due to Chris Everett for her revision of the English. The German Science Foundation (DFG) provided travelling funds to the principal author (Br 1121/23-1).

\section{References}

Błażewicz M, Heard WH (1999) First record of the family Gynodiastylidae Stebbing, 1912 (Crustacea: Malacostraca: Cumacea) from Antarctic waters with the description of Gynodiastylis jazdzewskii, a new species. Proc Biol Soc Wash 112:362-367

Brandt A (1999) On the origin and evolution of Antarctic Peracarida (Crustacea, Malacostraca). Sci Mar 63(Suppl 1):261-274

Brandt A, Barthel D (1995) An improved supra- and epibenthic sledge for catching Peracarida (Crustacea, Malacostraca). Ophelia 43:15-23

Brandt A, Mühlenhardt-Siegel, Siegel V (1998) An account of the Mysidacea (Crustacea, Malacostraca) of the Southern Ocean. Antarct Sci 10:3-11
Brandt A, Mühlenhardt-Siegel U, Schmidt A (1999) Density, diversity and community patterns of selected peracarid taxa (Malacostraca) in the Beagle Channel, South America. In: Schramm FR, von Vaupel Klein JC (eds) Crustaceans and the biodiversity crisis. Proceedings of the fourth international crustacean congress, Amsterdam, The Netherlands 1:541-558

Brenke N (2005) An epibenthic sledge for operations on marine soft bottom and bedrock. Mar Technol Soc J 39:10-21

Calman WT (1907) Crustacea II Cumacea. National Antarctic Expedition 1901-1904. Natl Hist Rep Zool 2:1-6

Calman WT (1917) The British Antarctic expedition 1910. Part 4 Cumacea. Natl Hist Rep Zool 3(5):145-156

Calman WT (1918) Cumacea and Phyllocarida. Sci Rep Austral Antarct Exped 1911-1914. Ser C 5(6):5-8

Clark M, Rowden A (2004) Marine biodiversity BioRoss 2004: expanding our knowledge of marine life in the Ross Sea. NIWA Water Atmos 12:24-25

Corbera J (2000) Systematics and distribution of cumaceans collected during BENTART-95 cruise around South Shetland Islands (Antarctica). Sci Mar 64:9-28

Corbera J, Ramos A (2005) Cumaceans from the Bellingshausen Sea and neighbouring waters. Ber Polarforsch 507:125-128

De Broyer C, Jazdzewski K (1996) Biodiversity of the Southern Ocean: towards a new synthesis for the Amphipoda (Crustacea). Boll Mu civ St nat Verona 20:547-568

Gamô S (1959) On a cumacean Crustacea (Diastylis corniculatus Hale) obtained by the second Japanese Antarctic research expedition (1957-58). Biol Res Jap Ant Res Exp 7:1-8

Gamô S (1987) Cumacean crustaceans obtained by the 26th Japanese Antarctic research expedition (1984-1985), with descriptions of four new species. Proc NIPR Symp Polar Biol $1: 145-160$

Hale HM (1937) Cumacea and Nebaliacea. BANZARE Rep Ser B 4(2):37-56

Hansen HJ (1908) Schizopoda and Cumacea. Résultats du Voyage de la "Belgica" 1897-1899. Rapp scient, Zool:1-20

Held C (2003) Molecular evidence for cryptic speciation within the widespread Antarctic crustacean Ceratoserolis trilobitoides (Crustacea, Isopoda). In: Huiskes AHL, Gieskes WWC, Rozema J, Schorno RML, van der Vies SM, Wolff WJ (eds) Antarctic biology in a global context. Backhuys Publishers, Leiden, pp 135-139

Held C, Wägele JW (2005) Cryptic speciation in the giant Antarctic isopod Glyptonotus antarcticus (Isopoda: Valvifera: Chaetiliidae). Sci Mar 69(Suppl 2):175-181

Jones NS (1971) The fauna of the Ross Sea. Part 8. Cumacea. NZ Dep Sci Industr Res Bull 206:33-44

Jones NS, Sanders HL (1972) Distribution of Cumacea in the deep Atlantic. Deep Sea Res 19:737-745

Jones NS (1984) The family Nannastacidae (Crustacea: Cumacea) from the deep Atlantic. Bull Br Mus nat Hist (Zool) 46(3):207-289

Ledoyer M (1973) Sur une petite collection des Cumacés recueillis aux Iles Kerguelen. Tethys 5:709-714

Ledoyer M (1977) Cumacés (Crustacea) des Iles Kerguelen, recueillis par le N.O. "La Japonaise" en 1972 et 1974 et par le M.S. "Marion-Dufresne" en 1974. CNFRA 42:193-213

Ledoyer M (1993) Cumacea (Crustacea) de la campagne EPOS 3 du R.V. Polarstern en mer de Weddell, Antarctique. J Nat Hist 27:1041-1096

Linse K, Brandt A, Hilbig B, Wegener G (2002) Composition and distribution of suprabenthic fauna in the south-eastern Weddell Sea and off King George Island. Antarct Sci 14:3-10

Lörz AN, di Renzo A, Nickel J (1999) Comparative analysis of three sampling gear types for marine macrobenthos. Ber Polarforsch 330:134-151 
Lörz AN, Brandt A (2003) Diversity of Peracarida (Crustacea, Malacostraca) caught in a suprabenthic sampler. Antarct Sci 15:433-438

Lomakina NB (1968) Kumovye raki (Cumacea) antarctičeskoj oblasti. Issl Fauny Morej 14:97-140

Mühlenhardt-Siegel U (1994) Leucon parasiphonatus, a new species (Crustacea: Cumacea: Leuconidae) from Antarctic waters. Helgoländer Meeresunters 48:79-88

Mühlenhardt-Siegel U (1996) Some remarks on the taxonomy of Antarctic Leuconidae (Cumacea: Crustacea) with a description of a new species Leucon intermedius n. sp. Helgoländer Meeresunters 50:391-408

Mühlenhardt-Siegel U (1999) On the biogeography of Cumacea (Crustacea, Malacostraca). A comparison between South America, the Subantarctic Islands, and Antarctica: present state of the art. Sci Mar 63(Suppl 1):295-302

Petrescu I (1991) Contributions to the knowledge of the family Leuconidae (Crustacea, Cumacea) with the description of three new species: Heteroleucon bacescui $\mathrm{n}$. sp., Leucon adelae n. sp. and Leucon meridithi $\mathrm{n}$. sp. Revue roumaine de Biologie (Biologie Animale) 36(1-2):15-20

Petrescu I, Wittman KJ (2003) Elements for a revision and notes on bionomy of the Cumacea (Crustacea: Peracarida) of the Weddell Sea (Antarctica). Material collected by the expedition ANTARKTIS-VIII/5 of R.V. "Polarstern" 1998/90. Zool Med Leiden 77:557-630

Pielou EC (1966) The measurement of diversity in different types of biological collections. J Theor Biol 13:131-144

Rehm P, Thatje S, Arntz WE, Brandt A, Heilmayer O (2006) Distribution and composition of macrozoobenthic communities along a Victoria-Land Transect (Ross Sea, Antarctica). Polar Biol 29:782-790

Roccatagliata D, Heard R (1992) Diastylopsis goeckei, a new species (Crustacea: Cumacea: Diastylidae) from Antarctic waters. Proc Biol Soc Wash 105:743-752

Sars GO (1887) Reports on the Cumacea collected by H.M.S. Challenger during the years 1873-1876. Rep Sci Res Voyage HMS Challenger 19(55):1-78
Schmidt A, Brandt A (2001) The tanaidacean fauna of the Beagle Channel (southern Chile) and its relationship to the fauna of the Antarctic continental shelf. Antarct Sci 13:420-429

Shannon CE, Weaver W (1949) The mathematical theory of communication. University of Illinois, Urbana, pp 1-117

Smith Jr WO, Nelson DM, DiTullio GR, Leventer AR (1996) Temporal and spatial patterns in the Ross Sea: Phytoplankton biomass, elemental composition, productivity and growth rates. J Geophys Res 101(C8):18455-18465

Thatje S, Hillenbrand CD, Larter R (2005) On the origin of Antarctic marine benthic community structure. Trends Ecol Evol 20(10):534-540

Wägele JW (1986) Polymorphism and distribution of Ceratoserolis trilobitoides (Eights, 1833) (Crustacea, Isopoda) in the Weddell Sea and synonymy with $C$. cornuta (Studer, 1879). Polar Biol 6:127-137

Waterhouse EJ (2001) Ross Sea region: a state of the environment report for the Ross Sea region of Antarctica New Zealand Antarctic Institute, Christchurch

Zimmer C (1902) Die Cumaceen. Ergebnisse der Hamburgischen Magelhanischen Sammelreise 2. L Friedrichsen, Hamburg, pp 1-18

Zimmer C (1907a) Neue Cumaceen aus den Familien Diastylidae und Leuconidae von der Deutschen und Schwedischen Südpolar-Expedition. Zool Anz 31:220-229

Zimmer C (1907b) Neue Cumaceen von der Deutschen und Schwedischen Südpolarexpedition aus den Familien der Cumiden, Vaunthompsoniiden, Nannastaciden und Lampropiden. Zool Anz 31:367-374

Zimmer C (1908) Die Cumaceen der Deutschen Tiefsee-Expedition. Wiss Ergeb dt Tiefsee-Exp "Valdivia” 8:155-196

Zimmer C (1909) Die Cumaceen der schwedischen Südpolarexpedition 1901-1903. Schwedische Südpolarexpedition 6(3):1-31

Zimmer C (1913) Die Cumaceen der Deutschen Südpolar-Expedition 1901-1903. Die Deutschen Südpolar-Expeditionen, 14(Zool 6):437-491

Zimmer C (1921) Einige neue und weniger bekannte Cumaceen des Schwedischen Reichsmuseums. Arkiv För Zoologi 13(21):1-9 